\title{
Knowledge and Academic Integrity Breach among Malaysian University Students
}

\author{
Nur Hafizah Yusoff*, Geraldine K. L. Chan, Nurul Atikah Zulkepli \\ Department of Anthropology and Sociology, Research Centre of Social, Development and Environment (PKPSP), Faculty of Social \\ Science and Humanities (FSSK), Universiti Kebangsaan Malaysia (UKM), 43600 Bangi, Selangor, Malaysia
}

Received October 6, 2020; Revised December 7, 2020; Accepted December 18, 2020

\section{Cite This Paper in the following Citation Styles}

(a): [1] Nur Hafizah Yusoff, Geraldine K. L. Chan, Nurul Atikah Zulkepli, "Knowledge and Academic Integrity Breach among Malaysian University Students," Universal Journal of Educational Research, Vol. 8, No. 12B, pp. 8376-8382, 2020. DOI: 10.13189/ujer.2020.082643.

(b): Nur Hafizah Yusoff, Geraldine K. L. Chan, Nurul Atikah Zulkepli (2020). Knowledge and Academic Integrity Breach among Malaysian University Students. Universal Journal of Educational Research, 8(12B), 8376-8382. DOI: 10.13189/ujer.2020.082643.

Copyright $\subseteq 2020$ by authors, all rights reserved. Authors agree that this article remains permanently open access under the terms of the Creative Commons Attribution License 4.0 International License

\begin{abstract}
The objective of this article is to evaluate the knowledge and sources of knowledge of academic integrity and the types of academic integrity breach among university students in Malaysia. A quantitative approach was used to obtain the data. A set of questionnaires was distributed to students from Universiti Kebangsaan Malaysia (UKM), Universiti Malaya (UM), Universiti Putra Malaysia (UPM) and Universiti Sains Islam Malaysia (USIM). A total of 1000 respondents were selected to answer the questionnaires. The data are presented in descriptive statistics using frequency and percentage. Based on the findings, there are different levels of knowledge of academic integrity. Besides, it also revealed that the respondents knew about academic integrity issues such as plagiarism and cheating. Sources of knowledge on academic integrity are family, friends, technology, and mass media. The findings conclude that students need to empower their academic integrity, strengthen their code of conduct so that they know that breach of academic integrity is wrong and should not be performed. If such actions are performed by them, they should know the negative consequences of that violation. Their behaviors could be more serious when they later finish their study and pursue their own career path.
\end{abstract}

Keywords Academic Integrity, Deviant Behaviors, Integrity, Plagiarism, University Students, Sociology

\section{Introduction}

Integrity is not a recent issue in occupation and academic. It is in fact one of the many issues discussed in academic perspective. Therefore, in general, integrity is important in making sure that individual carries out his responsibility with honesty and trust [30]. Having honesty, responsibility, trust, sincerity and transparency in performing work is essential within oneself. This is because such values help to build and shape one's integrity. These values will then be able to help people to avoid making mistakes and error [7]. In other words, integrity and ethics involve good acts in daily life and have a close relationship that is parallel to religious teaching and human's responsibilities [21].

The concept of integrity in general is the quality to be honest and fair in life. Integrity means honesty, perfection and strength, while having integrity is the attitude with integrity, honesty, and transparency. Apart from that, the word integrity originated from Latin word, 'integer' which means comprehensive, perfect, and strong unity [23].

Malaysia's National Integrity Plan defines integrity as an excellent quality that needs to be strongly and comprehensively held by all individuals. Besides, integrity also needs to be based on ethics that reflect life ethics [1]. Moreover, integrity is a level or state in which there is a balance between private spaces, autonomy and values of an individual. Integrity is perceived as a commitment that is demonstrated consistently and coherently in any action. The concept of integrity can also 
be defined as a set of beliefs towards one's capability to preserve self-morality without any compromise. Integrity at the workplace involves the attitude of the employee comprising justice, honesty and trustworthiness [11].

Integrity does not only exist at the workplace, rather it can be found in daily life. The use of technology in daily life contributes to more issues than before about integrity integration into various aspects. Academic integrity for instance, is discussed more today compared to back then. This is because academic integrity issues largely happen due to technological influences that have penetrated the social environment, especially the academia. The availability of academic websites, and access to relevant journals make it easier for such issue of academic integrity to happen, i.e. plagiarism. It is worsened by the attitudes of undergraduates who do not know that the breach of academic integrity is wrong. Furthermore, undergraduates are often described as the future leaders and the continuation of next generation. Undergraduates are important assets in the making of a developed country that also has a good competitive advantage. Hence, undergraduates should pursue not only good academic values but also high integrity value before joining the work force. If there is no proper care of integrity system and moral of undergraduates, it can bring negative impacts not only to the undergraduates but also to the system of a country [27]. Most people have failed to see the impact and the importance of one's moral values and integrity in shaping an honest society.

A research by Malaysian Institute of Integrity in 2017 on undergraduates involving three public universities in Malaysia showed that $35.8 \%$ undergraduates did not consider receiving gifts in the form of money, items, or services as bribes [1]. The lack of knowledge regarding the concept and value of integrity in a student can impact his occupational opportunities in the future. Besides, cases like cheating, certificate falsification and plagiarism can lead to bigger cases like bribery, misuse of power and dishonesty at work. The findings on the undergraduates clearly showed that the society in this country still perceive issues relevant to academic integrity as unserious despite being heavily discussed in the west. Therefore, due to the lack of research related to academic integrity and its importance, this study was carried out to ensure that students in higher education do not only have academic excellence but also have a high personality with integrity. The objective of this paper is to identify the knowledge on integrity concepts and their sources of that knowledge. Besides that, this paper wants to explore the knowledge and understanding of academic integrity by giving examples of behavior that often occur in academic.

\section{Literature Review}

Every Malaysian citizen is considered a human capital that needs proper care to ensure the development of the country. Human capital is very important especially in increasing current productivity and competitiveness [34]. To produce a successful human capital, education system plays a major role. Through a holistic education system, human capital with balanced spiritual and physical will be produced. Hence, it is the responsibility of educational institutions to emphasize not only on educational aspects but also on the good values for students to conquer while in the education world. If good moral values and high discipline are successfully applied, human capital will remain in line with social values, norms, and law regardless of the problems and challenges faced. The humans will not be easily influenced by external factors to breach the values and ethics that they have been holding on to [4].

Emilly Anak Sakai \& Mohd Dahlan [4] are more inclined towards values that are found within the youths (undergraduates of Universiti Malaysia Sabah UMS). The values are concerned with power, achievement, stimulation, self-direction, concordance, and safety which are concluded to have a significant relationship with the aspect of human well-being. Meanwhile, only hedonistic values do not have a direct relationship with human well-being. They also stated that there is a significant difference between male and female students in terms of well-being.

From the research outcome, it was found that the important values between male and female students are power value, hedonistic values, generosity, traditional values, and concordance. The analysis found that male students prioritize power value, hedonistic values, and stimulation, while lacking in values related to concordance, tradition, and generosity. In comparison to the female students, they prioritize the values of concordance, culture, and tradition, along with generosity. Such situations clearly show that female students display more maturity compared to males. Female students do not only think about themselves, but also other people in their surroundings compared to male students who tend to prioritize themselves [4]. Hence, it can be concluded that male students are more prone to taking control over situations and their actions show freedom (hedonism and stimulation) in each. Apart from that, they are also proud of themselves and consider themselves as matured enough if they possess such values.

The result is parallel with the outcome of research conducted by [4], that well-being is aimed to enhance one's quality of life and remove them from problem. Therefore, living healthily, safely, comfortably, and peacefully demonstrates well-being in life. Nevertheless, to achieve a good quality of life, the process must also happen in a good way. For instance, to have a comfortable life, one must work hard to get a better income. However, it is pointless to have a good quality of life but through bribery and breach of trust. Asmah Ahmad [2] also opined 
that there is a close relationship between the quality of life and well-being. This is because both are like magnets that pull each other together. If there is no good integrity within oneself, the magnet can pull that individual towards a dark path.

The Malaysian Institute of Integrity (IIM) conducted a survey among undergraduates who are from Universiti Kebangsaan Malaysia (UKM), Universiti Sains Malaysia (USM) and Universiti Teknologi Mara (UiTM). The survey was carried out in 2017 and the purpose was to know the perception of undergraduates towards bribery in Malaysia. Among the research outcome, 35.8\% respondents stated that receiving money or gift as a return from service given is not a form of bribery. Meanwhile, $37.3 \%$ respondents also stated that making a claim on accommodation for outside duty despite the accommodation provided is not an offence [1].

Other studies regarding undergraduates and academic integrity have also been conducted in and outside of the country. Academic dishonesty is a challenge to many academic institutions all over the world [15]. Jones [13] found that the majority of undergraduates were involved in academic dishonesty because of several reasons, for instance 92\% undergraduates admitted to performing dishonesty because they wanted to obtain good grades and $75 \%$ of them did that with the excuse that they were too busy with studies and assignments. In New Zealand, nine out of ten students were involved in academic dishonesty [33]. In 2005, McCabe [20] conducted a significant impact study comprising 80,000 undergraduates. His research outcome showed that in that year, $21 \%$ undergraduates had performed serious academic dishonesty at least once. Several $68 \%$ admitted doing assignment together and 63\% plagiarized. Harding, Carpenter and Finelli [7] found that 28\% undergraduates admitted to performing academic dishonesty during examination, [14] their research stated that $70 \%$ out of 50,000 bachelor students around the year 2002 to 2005 used to cheat and were involved in academic dishonesty. The data were collected from 60 campuses across the world.

Asian countries are not exempted, [17] their research showed that the percentage of academic dishonesty problem was $61.7 \%$. Galloway [6] in his research on 4316 undergraduates of tertiary institutions reported that nearly 93\% undergraduates had performed academic dishonesty at least once during their study period. Research carried out by [3] reported that $55.4 \%$ students in Japan cheated during the examination, while [22] found that $10 \%$ students used the "cut and paste" function from internet resources and $40 \%$ students used similar method in completing their project paper the previous year.

In Malaysian context, research regarding the integrity of undergraduates in study is still lacking. The research by [24] found that 82\% UiTM undergraduates had performed academic dishonesty. Students from Information
Technology faculty performed more academic dishonesty compared to other faculties, showing that the access to ICT facility and usage skills had eased the activity of academic dishonesty [19]. Ramlan Mustapha [27] conducted a study among Muslim students in Teaching Institute in 2016, and found that the mean for Muslim undergraduates' perceptions regarding the issue of academic dishonesty is at moderate level (2.33). The offence such as modifying other student's work and falsifying reference list each has a moderate mean score of 2.16. Meanwhile, $45 \%$ undergraduates admitted of not getting involved in academic dishonesty in 2014, and 37\% in 2015; the rest admitted having performed academic dishonesty before. More surprisingly, the outcome showed that $29 \%$ trainees performed academic dishonesty occasionally and $3.1 \%$ performed many times; the rest performed at least once. This ratio shows that such activity will tend to continue if it is not prevented [27].

\section{Materials and Methods}

\subsection{Process of Data Collecting}

This research used quantitative method and the reason why quantitative was chosen because we wanted to gather many respondents and to see the pattern of the answers. Therefore, a survey using the questionnaire form was used to obtain the intended data. The questions in the questionnaire survey were about the respondents' sociodemographic part (part A), comprehension about the concept of integrity (part B) and the respondents 'integrity in academic (part C). Questions in Part B and C consisted of questions drawn in Likert scale format. To help the researcher design the questionnaire, data and information from previous studies were used to help ease the process. Then, to validate the process, a questionnaire was sent to two field experts to get comments. After the comments were received, a few parts of the questionnaires had to be improved to ensure the problem of statement and research objectives were answered. After the revision of the questionnaires, the research data were collected.

\subsection{Sampling and Analyzing Data}

The researcher selected the respondents who are students from Universiti Malaya (UM), Universiti Kebangsaan Malaysia (UKM), Universiti Putra Malaysia (UPM) and Universiti Sains Islam Malaysia (USIM). The reason why the students from these four universities were selected was the research wanted to focus only on several public universities around the central zone of Malaysia. The respondents were selected through a purposive sampling method in which the criteria fixed was the thirdor fourth-year students in their final year at selected Public Higher Education Institutions. The researcher 
targeted the final year students as they have gone through academic life for three to four years and have more experiences of academic integrity breech compared to a freshie. Apart from that, they are also graduating and will soon pursue job. So, if they possess such attitude of academic integrity breech, it might be alarming as there is a potential that the same attitudes are brought to their workplace. A number of 1000 respondents answered the distributed questionnaire form. The distribution of questionnaires took three weeks. After all the questionnaires had been answered, the researchers processed and analyzed the data using the Statistical Package for Social Science (SPSS) application. The results of the data were presented in descriptive statistics namely in frequency and percentage forms.

\section{Findings and Discussion}

The number of male respondents was $45.0 \%$ while the total of female respondents was $55.0 \%$. Next, the distribution of respondents' age in this research is from 22 to 24 years old. Most respondents were about 23 years of age. Such situation was due to the selection of students among final year students. The distribution of respondents by academic institutions is 250 students for every selected university. The researcher did not specify which faculty in selecting the respondents from each of the public universities. This is because the researchers assumed that all students have the potentials to breach academic integrity while taking their courses.

\subsection{Knowledge and Sources of Knowledge about Integrity}

Based on the responses of the respondents about the concept of integrity, $75 \%$ respondents acknowledged that they knew about the integrity concept while the rest claimed that they did not know about integrity concept.

Table 1 shows the sources of respondents' knowledge about integrity concept. There are varieties of methods and mediums which helped in giving knowledge to the respondents about the general concept of integrity. Most respondents stated family as their important agent of socialization who shared general information related to integrity. The majority of respondents stated that they learned informally about what is integrity, honesty, and the importance of avoiding bribery from their family; parents or relatives, since they were teenagers. Despite not being exposed to the thorough concept of integrity, at least the respondents have heard about it. Apart from that, peers were also seen as socialization agents. Hence, the respondents said that they knew about the integrity concept from their peers.

Family as a primary socialization agent has been the main source of knowledge about integrity for $88 \%$ of the respondents. Family provides informal education of integrity to the respondents. Besides family, respondents spent most time with their friends. Therefore, it is not surprising that $57 \%$ of the respondents claimed to have been exposed about integrity concept from close friends from their high school and university. Mass media like the internet and newspaper also influenced the respondents in acquiring the knowledge about integrity. As seen from the answer distribution given by the respondents, it can be concluded that family is the primary socialization agent that became their source of knowledge about integrity. However, the respondents also obtained integrity knowledge from other multiple secondary socialization agents such as friends and mass media.

\subsection{Breach of Academic Integrity among Students}

Academic integrity refers to any offence that goes against the rules in academic field, whether it is committed by own self, third party or towards other people [18]. The offences that often happened in academic field are, plagiarism, ghost writing, cheating in examination, purchase of certificate, giving bribe to lecturer and others [11]. If the breach of academic integrity is performed, it will not only harm the students, but will also taunt the name and reputation of educational institution in general [16].

The availability of internet does not only bring benefits to people but can also impact its users negatively. The purpose of internet is to ease every day's life; for communication and to make work and education easier. Nevertheless, the accessibility of internet and fast speed internet also contribute towards plagiarism among students, particularly [9]. Plagiarism is an action which is perceived as wrong and breaching the ethics and law because an individual steals idea or work of other people without giving 'credit' or acknowledgement to the original writer [26].

Based on Table 2, it can be concluded that the respondents mostly get the idea of academic integrity. Nevertheless, there were some respondents who said that they did not understand or still chose to commit academic dishonesty despite knowing that such action is wrong. For instance, there were $21.8 \%$ respondents who gave negative reactions towards the statement that taking the idea without accurate references is a form of plagiarism although the statement is clearly correct.

In addition, 48.6\% respondents agreed and strongly agreed that not making references correctly is an exemption from offence. Moreover, 35.7\% also agreed and strongly agreed that taking materials from internet does not need references. These answers are displeasing because in academic field, referencing is very important. Referencing needs to be done to give acknowledgement to appropriate people. It is undeniable that internet sourcing is a trend among students nowadays. Easy, quick, and free 
are the reasons why students favor taking materials from the internet [8] as opposed to producing 'hardcopy' materials to complete their assignments. However, the action of not giving acknowledgement or references is a big academic offence.

A total of $67.8 \%$ respondents responded positively towards the statement of 'not making references to pictures, graph, and figure is a minor offence'. Figure, chart, picture, and graph are products of various reading resources and research conducted by the writers [29]. Therefore, taking the materials without references is a big academic offence. It is equal to stealing other people's work for free. Most respondents agreed (91.2\%) with the statement that 'acknowledgement must be given to original writer'. While, $8.8 \%$ respondents were unsure and did not agree to the statement. It should be reminded that, despite making changes to the sentences borrowed from the original writer, acknowledgement and references still need to be given. This is because the original idea came from the original writer. If there is no source of documentation and paraphrasing, it is categorized as plagiarism [25].

Apart from plagiarism, students also commit academic cheating and the results are shown in Table 3. Past research showed that cheating act in academic happened because of the pressure felt by the students. Such pressure came from parents, friends, and educators [28]. Besides, the education environment, that is the school, college or university, academic anxiety [31] also contribute to the cheating act among students. Based on Table 3, the responses given by the respondents were inclined towards positive answers. The respondents mostly realized that cheating act in academic field is a type of offence. Only a small group of respondents still did not know that cheating act is not allowed. $78.6 \%$ respondents stated that they agreed with the statement that copying from friends is not an offence. The act of copying academic task and such is among the common actions committed by students at schools and universities [5]. On the other hand, as much as $45.0 \%$ respondents replied to the statement that signing the attendance for friends who did not attend the lecture class is allowed. Such act is wrong as in fact is deceiving to the lecturer. It is easy to mark attendance on behalf of friends if the class has a big number of students. Therefore, it is difficult for the lecturer to identify which student did that. To avoid this from happening or recurring, lecturers can say out aloud the students' names and not distribute the attendance form for signature record.

A total of $63.2 \%$ respondents stated that paying somebody else to complete a task is not allowed. The rest of the respondents thought that such action of paying the third party to complete their academic task is not an offence. If the respondents performed such action, it shows their irresponsibility as if knowledge is a minor thing that can be traded with money. Academic institution has now become a business platform for some individuals. For instance, there are individuals who provide services to complete other people's assignments, exercises, and thesis with high payment. Such situations show that there are demands from the students, which lead to the widely spread ghostwriting [22].

Meanwhile, only $4.8 \%$ respondents claimed that bringing notes during the examination is not wrong. This opinion is not true at all as higher educational institutions have their own guidelines that forbid the students from bringing notes into the examination hall. If the student is caught, he or she will be punished in the form of failing in the subject grade, undergoing hearing in court, and then getting punished. It is the opposite to the concept of 'open book exam, where students can bring books and notes to answer the questions in the examination [10]. Apart from academic cheating in Table 3, the respondents were also generally asked about their opinion whether purchasing educational certificates is allowed. $97.2 \%$, which is the majority of them responded that such action is wrong and should not be performed. Now, there are many organizations that offer express certificates to students without having to attend lectures and examinations. All they must do is to pay a sum of money for the certificates. In Malaysia, such cases have also been reported especially involving the purchase of $\mathrm{PhD}$ certificates. The act of purchasing fake certificates is a very unethical act [12,32] that looks down upon the educational institution itself. Doctoral Degree certificate for instance, is the highest degree in educational institution and to possess it, a student needs to have a high level of academic knowledge and is able to apply all the academic knowledge into thesis writing. Furthermore, the student needs to defend the thesis through a verbal examination (viva voce). If the student passes the examination, then only he or she will be rewarded with $\mathrm{PhD}$ certificate that comes with the title 'Dr'. Therefore, it is very unfair for striving students to complete their $\mathrm{PhD}$ to obtain the 'Dr' title while there are other people out there who pay an amount of money just to get the same $\mathrm{PhD}$ certificate much easier and quicker.

Table 1. Source of knowledge

\begin{tabular}{|c|c|c|}
\hline & Total Number (N) & Percentage (\%) \\
\hline Family & 880 & 88.0 \\
\hline Friends & 570 & 57.0 \\
\hline School & 525 & 52.5 \\
\hline Internet & 470 & 47.0 \\
\hline Television & 677 & 67.7 \\
\hline Newspaper & 285 & 28.5 \\
\hline Others & 125 & 12.5 \\
\hline
\end{tabular}


Table 2. Plagiarism

\begin{tabular}{|c|c|c|}
\hline & $\begin{array}{c}\text { Positive (Agree } \\
\text { \& Strongly } \\
\text { Agree \%) }\end{array}$ & $\begin{array}{c}\text { Negative (Disagree, } \\
\text { Strongly Disagree) }\end{array}$ \\
\hline $\begin{array}{c}\text { Taking idea without } \\
\text { correct references is } \\
\text { plagiarism }\end{array}$ & 78.2 & 21.8 \\
\hline $\begin{array}{c}\text { Not referencing } \\
\text { correctly is an } \\
\text { exemption from } \\
\text { Offence }\end{array}$ & 48.6 & 51.4 \\
\hline $\begin{array}{c}\text { Using materials from } \\
\text { Internet does not } \\
\text { require references }\end{array}$ & 35.7 & 64.3 \\
\hline $\begin{array}{c}\text { Acknowledgement } \\
\text { must be given to } \\
\text { original writer }\end{array}$ & 91.2 & 8.8 \\
\hline $\begin{array}{c}\text { Not making references } \\
\text { to pictures, graph and } \\
\text { figure is a minor } \\
\text { offence }\end{array}$ & 67.8 & 32.2 \\
\hline
\end{tabular}

Table 3. Cheating

\begin{tabular}{|c|c|c|}
\hline $\begin{array}{c}\text { Copying from } \\
\text { friend is not a type } \\
\text { of offence }\end{array}$ & $\begin{array}{c}\text { Positive (Agree \& } \\
\text { Strongly Agree \%) }\end{array}$ & $\begin{array}{c}\text { Negative (Disagree, } \\
\text { Strongly Disagree) }\end{array}$ \\
\hline $\begin{array}{c}\text { Signing } \\
\text { attendance for } \\
\text { friends who did } \\
\text { not attend the } \\
\text { lecture class/ } \\
\text { tutorial }\end{array}$ & 78.6 & 21.4 \\
\hline $\begin{array}{c}\text { Paying somebody } \\
\text { else to complete } \\
\text { the task is allowed }\end{array}$ & 35.0 & 55.0 \\
\hline $\begin{array}{c}\text { Bring notes during } \\
\text { examination is } \\
\text { allowed }\end{array}$ & 46.8 & 63.2 \\
\hline
\end{tabular}

\section{Conclusions}

Integrity is a concept that must be acknowledged, understood, and acted upon by every individual. From the findings, it can be concluded that the students have some knowledge on integrity and that knowledge came from various sources. They are also aware on the dos and don'ts as a student. However, although they possess such knowledge, there is no guarantee they will not get involved in academic dishonesty. In the end, it is all about choices that they make and if they get caught, they know what consequences are waiting for them. It is difficult to control one's integrity, let alone other people's integrity. Everyone should ensure that self-integrity is in control so that they will not be easily influenced by outsiders who try to downgrade their self-integrity. Academic integrity in the academic field is equally important as integrity at the workplace. Academic institutions are responsible to prepare students with knowledge and integrity value that they should embrace before getting employed. If the institutions fail, it is not impossible for the students who used to breach academic integrity to commit integrity offence in the workplace later.

Academic institution is a place for students to receive knowledge from lecturers with caliber. However, not all students pay attention to the aspect of academic integrity throughout the whole three or four years of study at the university. Students sometimes tend to go against the values and norms for the sake of fulfilling their own individual needs and desires. Hence, it is not surprising if there are students who practice plagiarism, cheating in the assignment and during the examination and make use of their friends for the sake of their own academic intentions. If this academic integrity issue is not handled properly, it will give a negative image to the academic institution in general. Preventive action and proactive monitoring need to be done by all the stakeholders especially the educational institutions themselves to ensure that all students abide by the academic rules provided. Besides, education and the empowerment of academic integrity value need to be enhanced so that students are always alert with the actions that could breach the integrity at university.

\section{Acknowledgments}

The authors would like to express gratitude as this work was supported by the Research Grant GGPM-208-073 from Universiti Kebangsaan Malaysia

\section{REFERENCES}

[1] Anis Yusal Yusoff, Zarina Mohamad Amin, "Laporan hasil kajian persepsi mahasiswa mengenai rasuah di Malaysia”. Institut Integriti Malaysia, 2017.

[2] Asmah Ahmad, "Kualiti hidup dan pengurusan persekitaran di Malaysia”, Prosiding Seminar Kebangsaan Pengurusan Persekitaran Bangi: Pusat Pengajian Siswazah UKM, 2005.

[3] Diekhoff G M., LaBeff E E., Shinohara K., Ysukawa K, "College cheating in Japan and the United States", Research in Higher Education, Vol. 40, No. 3, pp. 343-353, 2015

[4] Emilly Anak Sakai, Mohd Dahlan A. Malek, "Konsep integriti dan nilai murni terhadap kesejahteraan hidup dalam kalangan pelajar universiti yang tinggal di bandar dan luar bandar: Satu kajian di Universiti Malaysia Sabah”, Seminar Kebangsaan Integriti Keluarga, Julai., 2014.

[5] Friedman A., Blau I., Eshet-Alkalai Y, "Cheating and feeling honest: Committing and punishing analog versus digital academic dishonesty behaviors in higher education”, Interdisciplinary Journal of e-Skills and Lifelong Learning, Vol. 12, pp. 193-205, 2016. DOI:https://doi.org/10.28945/3 629 .

[6] Galloway M K, "Cheating in advantaged high schools: Prevalence, justifications, and possibilities for change. Ethics and Behaviour”, Vol. 22, No. 5, pp. 378-399, 2012. 
[7] Harding T S., Carpenter D D., Finelli C J, “Does academic dishonesty relate to unethical behaviour in professional practice? An exploratory study”, Science and Engineering Ethics, Vol. 10, pp. 311-324, 2004.

[8] Heckler N C., Forde D R, "The role of cultural values in plagiarism in higher education", Journal of Academic Ethics, Vol. 13, No. 1, pp. 61-75, 2015. DOI: https://doi.org/10.100 7/s10805-014-9221-3.

[9] Hu G., Lei J, "Investigating Chinese university students' knowledge of and attitudes toward plagiarism from an integrated perspective”, Language Learning, Vol. 62, No. 3, pp. 813-850, 2012. DOI: https://doi.org/10.1111/j.1467-99 22.2011.00650.x

[10] Ioannidou M, “Testing and life-long learning: Open-book and closed-book examination in a university course". Studies in Educational Evaluation, Vol. 23, No. 2, pp. 131-139, 2007.

[11] John L., Loewenstein G., Rick S, “Cheating more for less: Upward social comparisons motivate the poorly compensated to cheat”, Organizational Behavior and Human Decision Processes, Vol. 123, pp. 101-109, 2014.

[12] Johnson C, "Credentialism and the proliferation of fake degrees: The employer pretends to need a degree; the employee pretends to have one", Hofstra Labor and Employment Law Journal, Vol. 23, No. 2, pp. 269-343, 2006.

[13] Jones D R L, “Academic dishonesty: Are more students cheating?”, Business Communications Quarterly, Vol. 74, pp. 141-150, 2011.

[14] Josien L., Broderick B, "Cheating in higher education: The case of multi-methods cheaters", Academy of Educational Leadership Journal, Vol. 17, No. 2, pp. 93-105, 2013.

[15] Jurdi H., Hage H S., Chow P H, “Academic dishonesty in the Canadian classroom: Behaviour of a sample of university student”, Canadian Jurnal of Higher Education, Vol. 41, No. 3, pp. 1-35, 2011.

[16] Lang J M, “Cheating Lessons: Learning from Academic Dishonesty”, Harvard University Press, 2013, pp. 134-144.

[17] Lin C H S., Wen L Y M, “Academic dishonesty in higher education: A nationwide study in Taiwan”, Higher Education, Vol. 54, No. 1, pp. 85-97, 200.

[18] Macfarlane B., Zhang J., Pun A, “Academic integrity: A review of the literature", Studies in Higher Education, Vol. 39, No. 2, pp. 339-358, 2014.

[19] Mahmoud Poorian, Mohammad Javad Nekooei, Yusof Boon, "Academic cheating in higher education. The effect of a student development approach: A study at Universiti Teknologi Malaysia.”, IOSR Journal of Research \& Method in Higher Education, Vol. 1, No. 6, pp 40- 43, 2013.

[20] McCabe D L, "Cheating among college and university students: A North American perspective”, International Journal for Educational Integrity, Vol. 1, No. 1, pp. 65-74, 2005.

[21] Megat Ayob Megat Ariffin, Abd Halim Ahmad, "Kepentingan budaya integriti dan etika kerja dalam organisasi di Malaysia: Suatu tinjauan umum', Geografia-Malaysian Journal of Society and Space, Vol. 12, No. 9, pp. 138-149, 2016.

[22] Mitchell T., Carroll J, “Academic and research misconduct in the Ph.D: Issues for students and supervisors”, Nurse Education Today, Vol. 28, pp. 218-226, 2008.

[23] Yusoff N H, "Integriti akademik dalam kalangan mahasiswa Universiti Kebangsaan Malaysia (UKM)”, Malaysian Journal of Society and Space, Vol. 15, No. 4, pp. 73-83, 2019.

[24] Nursiha Saidin, Nurliyana Isa, "Investigating academic dishonesty among language teacher trainees: The why and how of cheating”, Procedia-Social and Behavioral Sciences, Vol. 90, pp. 522-529, 2013.

[25] Park C, “In other (people’s) words: Plagiarism by university students: Literature and lessons. Assessment and Evaluation in Higher Education, Vol. 28, No. 5, pp. 471-488, 2010. DOI: https://doi.org/ 10.1080/02602930301677

[26] Pecorari D., Petrić B, "Plagiarism in second-language writing” Language Teaching, Vol. 47, No. 3, pp. 269-302, 2014. DOI: https://doi.org/ 10.1017/S0261444814000056

[27] Ramlan Mustapha, “Ketidakjujuran akademik dalam kalangan mahasiswa muslim di Malaysia: Analisis perbandingan tahun 2014-2015”, Jurnal Kurikulum \& Pengajaran Asia Pasifik, Vol. 40, No. 1, pp. 41-55, 2016.

[28] Sarita R D, “Academic cheating among students: Pressure of parents and teachers", International Journal of Applied Research, Vol. 1, No. 10, pp. 793-797, 2015.

[29] Sureda-Negre J., Comas-Forgas R., Oliver-Trobat M F, "Academic plagiarism among secondary and high school students: Differences in gender and procrastination", Comunicar, Vo. 22, No. 44, pp. 103-110, 2015. DOI: https://doi.org/10.3916/C44- 2015-11

[30] Wayandiana Abdullah, Rahimah Abdul Aziz, "Integriti dan kesedaran polis orang asli terhadap rasuah”, Dlm. Rahimah Abdul Aziz, Mohamad Fauzi Sukimi \& Nur Hafizah Yusoff (pnyt.), Malaysia: Pembangunan negara dan kerencaman isu sosial, Penerbit Universiti Kebangsaan Malaysia, 2019, pp. 118-129.

[31] Wilkinson J, "Staff and student perceptions of plagiarism and cheating", International Journal of Teaching and Learning in Higher Education, Vol. 20, No. 2, pp. 98-105, 2009.

[32] Williams K M., Nathanson C., Paulhus D, "Identifying and profiling scholastic cheaters: Their personality, cognitive ability and motivation”, Journal of Experimental Psychology: Applied, Vol. 16, pp. 293-307, 2010.

[33] Williams M W M., Willliams M N, “Academic dishonesty, self-control and general criminality: Prospective and retrospective study of academic dishonesty in a New Zealand university”, Ethics \& Behavior, Vol. 22, No. 2, pp. 89-112, 2003, 2012.

[34] Joanna Bunga Noah, Azlina Abdul Aziz, "A Case Study on the Development of Soft Skills among TESL Graduates in a University," Universal Journal of Educational Research, Vol. 8, No. 10, pp. 4610-4617, 2020. DOI: 10.13189/ujer.2020.0 81029 . 